\title{
Effect of Biostimulants Added to Postemergence Herbicides in Corn, Oats and Winter Wheat
}

\author{
Nader Soltani*, Christy Shropshire, Peter H. Sikkema \\ University of Guelph Ridgetown Campus, Ridgetown, Canada \\ Email: 'soltanin@uoguelph.ca
}

Received 24 April 2015; accepted 24 May 2015; published 28 May 2015

Copyright (C) 2015 by authors and Scientific Research Publishing Inc.

This work is licensed under the Creative Commons Attribution International License (CC BY).

http://creativecommons.org/licenses/by/4.0/

c) (i) Open Access

\begin{abstract}
There is limited information available on the effect of biostimulants such as Crop Booster or RR SoyBooster on corn, oats and winter wheat under Ontario environmental conditions. A total of 37 field experiments were conducted in corn, oats and winter wheat at two locations (Ridgetown and Exeter, Ontario, Canada) to evaluate the effect of Crop Booster or RR SoyBooster on crop injury, weed control and yield. The addition of Crop Booster to glyphosate did not affect weed control or corn yield except at 4 weeks after herbicide application (WAA) when control of pigweed species was increased by $1 \%$ and at 4 and 8 WAA when control of common lambsquarters was reduced by $1 \%$. The addition of RR SoyBooster to glyphosate did not affect crop injury, weed control or corn yield. The addition of Crop Booster to glyphosate + topramezone + atrazine did not affect crop injury, weed control or corn yield except at 4 WAA when control of common ragweed was reduced by $1 \%$. The tank mix of Crop Booster with glyphosate + thiencarbazone-methyl did not affect crop injury, weed control or corn yield except at 4 WAA when control of green foxtail and annual grasses were reduced by $2 \%$ and $1 \%$, respectively. The addition of Crop Booster to bromoxynil/ MCPA had no significant effect on crop injury, weed control or yield of oats or winter wheat.
\end{abstract}

\section{Keywords}

Cereals, Injury, Height, Herbicide, Tolerance, Yield

\section{Introduction}

Wheat (Triticum aestivum L.), oats (Avena sativa L.) and corn (Zea mays L.) are three important field crops *Corresponding author.

How to cite this paper: Soltani, N., Shropshire, C. and Sikkema, P.H. (2015) Effect of Biostimulants Added to Postemergence Herbicides in Corn, Oats and Winter Wheat. Agricultural Sciences, 6, 527-534. 
grown in Canada [1]. Canada produces nearly 25,000,000 tonnes of wheat, 3,000,000 tonnes of oats and 11,000,000 tonnes of corn annually making it the $2^{\text {nd }}, 7^{\text {th }}$ and $11^{\text {th }}$ largest wheat, oats and corn producer in the world, respectively [1] [2]. Intensive agronomic practices, including proper weed management and plant nutrition, are needed for profitable production of winter wheat, oats and corn.

Biostimulants have been marketed by agricultural products companies for enhancing crop growth and yield of various crops for a number of years. Biostimulants have been defined as compounds, substances and other products such as microorganisms, trace elements, enzymes, plant growth regulators that when applied in small quantities to plants or soils can enhance plant growth and development by increasing the efficiency of physiological process within plants [3] [4]. Biostimulants have been reported to increase crop efficiency and enhance nutrient availability, water-holding capacity, increase antioxidants, enhance metabolism and increase chlorophyll production in plants [4]-[11].

Crop Booster and RR SoyBooster are two biostimulants developed by Axter Agrosciences Inc. (895, Chemin Benoit, Mont-St-Hilaire, Quebec, J3G 4S6, Canada) for use in fruits, vegetables and field crops to enhance vigor and foliage development [12]-[14]. Crop Booster contains 15\% total nitrogen, 3\% phosphoric acid $\left(\mathrm{P}_{2} \mathrm{O}_{5}\right)$, 6\% soluble potash $\left(\mathrm{K}_{2} \mathrm{O}\right), 0.02 \%$ boron, $0.05 \%$ chelated manganese, $0.05 \%$ molybdenum, $0.05 \%$ chelated zinc, and 0.5\% E.D.T.A. (chelating agent) [13]. RR SoyBooster composition is exactly the same as Crop Booster except for its total nitrogen which is $6 \%$ and available phosphoric acid $\left(\mathrm{P}_{2} \mathrm{O}_{5}\right)$ which is $18 \%$ [14].

According to the developers, Crop Booster compensates for plant's inability for nutrient uptake under stress from the soil by increasing foliar tissue nutrient concentration which enables plants to produce the enzymes and organic acid needed to combat stress [12]. Crop Booster is also promoted by the Axter Agrosciences Inc. as a biostimulant that works synergistically with herbicides to decrease stresses that may be caused by the use of post emergence herbicides in crops [12].

Ontario producers need information on the effect of biostimulants such as Crop Booster or RR SoyBooster on crop growth and weed control to make informed decisions on their use in order to maximize farm profitability. The demand on growers to minimize per unit cost of production is increasing. In the absence of clear data on the effect of biostimulants such as Crop Booster or RR SoyBooster on crop injury, weed control and crop yield, Ontario growers and ag-retailers rely on their "best guess" when to use these products. This can result in the application of ineffective products which do not address crop growth or yield or weed problems and results low return on investment, reduced profitability and unnecessary loading of chemicals in the environment. Limited information exists on the effects of the co-application of Crop Booster or RR SoyBooster with commonly used herbicides in corn, oats and winter wheat under Ontario environmental conditions.

The objective of this study was to evaluate if there is any benefit of adding Crop Booster or RR SoyBooster to post emergence herbicides that are commonly used in corn, oats and winter wheat in Ontario.

\section{Materials and Methods}

There were a total of 29 field experiments in corn conducted at the Huron Research Station, Exeter, Ontario and University of Guelph Ridgetown Campus, Ridgetown, Ontario. Studies with the addition of Crop Booster to glyphosate (total of 6) were conducted at Exeter in 2003 and at Ridgetown in 2002 (2 trials), 2003 (1 trial) and 2004 (2 trials). Studies with the addition of RR SoyBooster to glyphosate (total of 7) were conducted at Exeter in 2003 and at Ridgetown in 2002 (2 trials), 2003, 2004 (2 trials) and 2006. Studies with the addition of Crop Booster to glyphosate + topramezone + atrazine (total of 8) were conducted at Exeter and Ridgetown in 2010, 2012, 2013 and 2014. Studies with the addition of Crop Booster to glyphosate + thiencarbazone/tembotrione (total of 8) were conducted at Exeter and Ridgetown in 2011, 2012, 2013 and 2014. There were also 4 experiments in oats and 4 experiments in winter wheat at the Huron Research Station, Exeter, Ontario in 2004 and 2005 (2 studies in each year for each crop). All field trials were established as a randomized complete block design with four replications. Treatments are listed in Tables 1-4 for corn, Table 5 for oats and Table 6 for winter wheat experiments.

Field plots were $2 \mathrm{~m}$ wide and 8 or $10 \mathrm{~m}$ long. Corn was seeded at 80,000 seeds ha $^{-1}$ in rows that were spaced $0.75 \mathrm{~m}$ apart at a depth of $4 \mathrm{~cm}$ in early to late May of each year. Oats were seeded with a double disc drill at $140 \mathrm{~kg} \cdot \mathrm{ha}^{-1}$ in rows spaced $17.5 \mathrm{~cm}$ apart at a depth of $4 \mathrm{~cm}$ in late April. Winter wheat was seeded with a double disc drill at $150 \mathrm{~kg} \cdot \mathrm{ha}^{-1}$ in rows spaced $17.5 \mathrm{~cm}$ apart at a depth of $4 \mathrm{~cm}$ in mid-September to late October. 
Table 1. Comparison of weed control 4 and 8 WAA, and yield for glyphosate alone vs glyphosate plus Crop Booster in Roundup Ready corn. Values for the weedy check were not included in the analysis ${ }^{\mathrm{a}}$.

\begin{tabular}{|c|c|c|c|c|c|c|}
\hline \multirow{3}{*}{ Weed } & \multirow{3}{*}{ Treatment } & \multicolumn{5}{|c|}{ Control } \\
\hline & & Rate & \multirow{2}{*}{4 WAA } & \multirow{2}{*}{ (\%) } & \multirow{2}{*}{8 WAA } & \\
\hline & & $\mathrm{ha}^{-1}$ & & & & \\
\hline \multirow[t]{2}{*}{ ABUTH } & Glyphosate & $900 \mathrm{~g}$ aе & 98 & & 96 & \\
\hline & Glyphosate + Crop Booster & $900 \mathrm{~g}$ ae $+2 \mathrm{~L}$ & 97 & & 96 & \\
\hline \multirow[t]{2}{*}{ AMASS } & Glyphosate & $900 \mathrm{~g}$ ae & 98 & $* *$ & 97 & \\
\hline & Glyphosate + Crop Booster & 900 g ae $+2 L$ & 99 & & 98 & \\
\hline \multirow[t]{2}{*}{ AMBEL } & Glyphosate & $900 \mathrm{~g}$ ae & 95 & & 98 & \\
\hline & Glyphosate + Crop Booster & 900 g ai $+2 L$ & 96 & & 97 & \\
\hline \multirow[t]{2}{*}{ CHEAL } & Glyphosate & 900 g aе & 99 & * & 98 & * \\
\hline & Glyphosate + Crop Booster & $900 \mathrm{~g}$ ae $+2 \mathrm{~L}$ & 98 & & 97 & \\
\hline \multirow[t]{3}{*}{ GGGAN } & Glyphosate & $900 \mathrm{~g}$ ae & 99 & & 97 & \\
\hline & Glyphosate + Crop Booster & $900 \mathrm{~g}$ ae $+2 \mathrm{~L}$ & 99 & & 97 & \\
\hline & & & $\left(\mathrm{MT} \mathrm{ha}^{-1}\right)$ & & & \\
\hline \multirow[t]{3}{*}{ Yield } & Weedy check & & 4.54 & & & \\
\hline & Glyphosate & $900 \mathrm{~g}$ ae & 8.79 & & & \\
\hline & Glyphosate + Crop Booster & $900 \mathrm{~g}$ ae $+2 \mathrm{~L}$ & 9.01 & & & \\
\hline
\end{tabular}

${ }^{a}$ Abbreviations: ABUTH, velvetleaf; AMASS, green or redroot pigweed; AMBEL, common ragweed; CHEAL, common lambsquarters; GGGAN, annual grass; WAA, weeks after herbicide application. Significance of contrasts comparing glyphosate alone with glyphosate plus Crop Booster denoted by ${ }^{*}$ for $\mathrm{P}<0.10$ and ${ }^{* *}$ for $\mathrm{P}<0.05$ beside the means.

Table 2. Comparison of weed control 4 and 8 WAA, and yield for glyphosate alone vs glyphosate plus RR SoyBooster. Values for the weed-free check were not included in the contrasts ${ }^{\mathrm{a}}$.

\begin{tabular}{|c|c|c|c|c|}
\hline \multirow{3}{*}{ Weed } & \multirow{3}{*}{ Treatment } & \multirow{3}{*}{ Rate $\mathrm{ha}^{-1}$} & \multicolumn{2}{|c|}{ Control } \\
\hline & & & 4 WAA & 8 WAA \\
\hline & & & \multicolumn{2}{|c|}{$(\%)$} \\
\hline \multirow[t]{2}{*}{ ABUTH } & Glyphosate & $900 \mathrm{~g}$ ae & 97 & 96 \\
\hline & Glyphosate + RR SoyBooster & $900 \mathrm{~g}$ ae $+2 \mathrm{~L}$ & 97 & 96 \\
\hline \multirow[t]{2}{*}{ AMASS } & Glyphosate & $900 \mathrm{~g}$ ae & 98 & 96 \\
\hline & Glyphosate + RR SoyBooster & $900 \mathrm{~g}$ ae $+2 \mathrm{~L}$ & 98 & 97 \\
\hline \multirow[t]{2}{*}{ AMBEL } & Glyphosate & $900 \mathrm{~g}$ ae & 97 & 98 \\
\hline & Glyphosate + RR SoyBooster & 900 g ae $+2 \mathrm{~L}$ & 97 & 97 \\
\hline \multirow[t]{2}{*}{ CHEAL } & Glyphosate & $900 \mathrm{~g}$ ae & 99 & 97 \\
\hline & Glyphosate + RR SoyBooster & $900 \mathrm{~g}$ ae $+2 \mathrm{~L}$ & 98 & 98 \\
\hline \multirow[t]{2}{*}{ SETVI } & Glyphosate & $900 \mathrm{~g}$ ae & 99 & 97 \\
\hline & Glyphosate + RR SoyBooster & $900 \mathrm{~g}$ ae $+2 \mathrm{~L}$ & 99 & 98 \\
\hline \multirow[t]{3}{*}{ GGGAN } & Glyphosate & $900 \mathrm{~g}$ ae & 98 & 97 \\
\hline & Glyphosate + RR SoyBooster & 900 g ae $+2 \mathrm{~L}$ & 98 & 97 \\
\hline & & & $\left(\mathrm{MT} \mathrm{ha}^{-1}\right)$ & \\
\hline \multirow[t]{3}{*}{ Yield } & Weedy check & & 3.09 & \\
\hline & Glyphosate & $900 \mathrm{~g}$ ae & 8.79 & \\
\hline & Glyphosate + SoyBooster & $900 \mathrm{~g}$ ae $+2 \mathrm{~L}$ & 8.92 & \\
\hline
\end{tabular}

a Abbreviations: ABUTH, velvetleaf; AMASS, green or redroot pigweed; AMBEL, common ragweed; CHEAL, common lambsquarters; GGGAN, annual grass; SETVI, green foxtail; WAA, weeks after herbicide application. 'Significance of contrasts comparing glyphosate alone with glyphosate plus SoyBooster denoted by ${ }^{*}$ for $\mathrm{P}<0.10$ and ${ }^{* *}$ for $\mathrm{P}<0.05$ beside the means. 
Table 3. Comparison of weed control 4 and 8 WAA, and yield for glyphosate + topramezone + atrazine alone vs glyphosate + topramezone + atrazine + Crop Booster in Roundup Ready corn. Values for the weedy check were not included in the analysis $^{\mathrm{a}}$.

\begin{tabular}{|c|c|c|c|c|}
\hline \multirow{3}{*}{ Weed } & \multirow{3}{*}{ Treatment $^{\mathrm{b}}$} & & \multicolumn{2}{|c|}{ Control $^{\mathrm{C}}$} \\
\hline & & Rate & $\begin{array}{c}4 \\
\text { WAA }\end{array}$ & $\begin{array}{c}8 \\
\text { WAA }\end{array}$ \\
\hline & & $\mathrm{ha}^{-1}$ & \multicolumn{2}{|c|}{ (\%) } \\
\hline \multirow[t]{2}{*}{ ABUTH } & Glyphosate + topramezone + atrazine & $900 \mathrm{~g}$ ae $+12.5 \mathrm{~g}$ ai $+500 \mathrm{~g}$ ai & 94 & 91 \\
\hline & Glyphosate + topramezone + atrazine + Crop Booster & $900 \mathrm{~g}$ ae $+12.5 \mathrm{~g}$ ai $+500 \mathrm{~g}$ ai $+2 \mathrm{~L}$ & 96 & 92 \\
\hline
\end{tabular}

AMASS

Glyphosate + topramezone + atrazine

Glyphosate + topramezone + atrazine + Crop Booster

$900 \mathrm{~g}$ ae $+12.5 \mathrm{~g}$ ai $+500 \mathrm{~g}$ ai
$900 \mathrm{~g}$ ae $+12.5 \mathrm{~g}$ ai $+500 \mathrm{~g}$ ai $+2 \mathrm{~L}$

99

AMBEL

$$
\text { Glyphosate + topramezone + atrazine }
$$

Glyphosate + topramezone + atrazine + Crop Booster

$900 \mathrm{~g}$ ae $+12.5 \mathrm{~g}$ ai $+500 \mathrm{~g}$ ai

CHEAL

$$
\text { Glyphosate + topramezone + atrazine }
$$

Glyphosate + topramezone + atrazine + Crop Booster

SETVI

$$
\text { Glyphosate + topramezone + atrazine }
$$

Glyphosate + topramezone + atrazine + Crop Booster

Glyphosate + topramezone + atrazine

GGGAN

Glyphosate + topramezone + atrazine + Crop Booster

$900 \mathrm{~g}$ ae $+12.5 \mathrm{~g}$ ai $+500 \mathrm{~g}$ ai

$$
900 \mathrm{~g} \text { ae }+12.5 \mathrm{~g} \text { ai }+500 \mathrm{~g} \text { ai }
$$

\title{
$\left(\mathrm{MT} \mathrm{ha}^{-1}\right.$ )
}

Yield

$$
\text { Weedy check }
$$

Glyphosate + topramezone + atrazine + Crop Booster

$$
\begin{array}{cc}
900 \text { g ai }+12.5 \text { g ai }+500 \text { g ai } & 12.97 \\
900 \text { g ai }+12.5 \text { g ai }+500 \text { g ai }+2 \text { L } & 13.08
\end{array}
$$

\begin{abstract}
${ }^{a}$ Abbreviations: ABUTH, velvetleaf; AMASS, green or redroot pigweed; AMBEL, common ragweed; CHEAL, common lambsquarters; GGGAN, annual grass; SETVI, green foxtail; WAA, weeks after herbicide application. ${ }^{\mathrm{b} S i g n i f i c a n c e ~ o f ~ c o n t r a s t s ~ c o m p a r i n g ~ g l y p h o s a t e ~}+$ topramezone + atrazine alone with glyphosate + topramezone + atrazine + Crop Booster denoted by ${ }^{*}$ for $\mathrm{P}<0.10$ and ${ }^{* *}$ for $\mathrm{P}<0.05$ beside the means. ${ }^{\mathrm{C}}$ Assist $(1.25 \%$ $\mathrm{v} / \mathrm{v}$ ) included in treatments for 2 of the 4 years.
\end{abstract}

Herbicide treatments were applied with a $\mathrm{CO}_{2}$-pressurized back-pack sprayer equipped with Hypro ULD12002 nozzle tips (Hypro, New Brighton, MN) calibrated to deliver $200 \mathrm{~L} \cdot \mathrm{ha}^{-1}$ of water at $200 \mathrm{kPa}$. Herbicide applications were made with a $1.5 \mathrm{~m}$ boom with four nozzles spaced $50 \mathrm{~cm}$ apart.

Estimate of crop injury was visually estimated on a scale of 0 (no injury) to $100 \%$ (complete plant death) at 1 and 4 weeks after herbicide application (WAA). Weed control was visually estimated on a scale of 0 (no control) to $100 \%$ (complete weed control) at 4 and 8 weeks after herbicide application (WAA). Crops were harvested from each plot with a small plot combine, weight and seed moisture content were recorded, and yields were adjusted to $15.5 \%$ seed moisture content for corn, $13.5 \%$ seed moisture content for oats and $14 \%$ seed moisture content for winter wheat.

Data were analyzed as an RCBD using PROC MIXED in SAS 9.2. Herbicide treatment was considered a fixed effect, while environment (year-location combinations), the interaction between environment and herbicide treatment, and replicate nested within environment were considered random effects. Significance of the fixed effect was tested using F-test and random effects were tested using a Z-test of the variance estimate. The UNIVARIATE procedure was used to test data for normality and homogeneity of variance. The untreated check (for injury ratings) was excluded from the analysis. To satisfy the assumptions of the variance analyses, if needed, weed control ratings were arcsine square root transformed. Treatment comparisons were made using contrasts. Data compared on the transformed scale were converted back to the original scale for presentation of results. 
Table 4. Comparison of weed control 4 and 8 WAA, and yield for glyphosate + thiencarbazone/tembotrione alone vs glyphosate + thiencarbazone/tembotrione + Crop Booster in Roundup Ready corn. Values for the weedy check were not included in the analysis ${ }^{\mathrm{a}}$.

\begin{tabular}{|c|c|c|c|c|c|}
\hline \multirow{3}{*}{ Weed } & \multirow{3}{*}{ Treatment } & \multicolumn{4}{|c|}{ Control $^{\mathrm{b}}$} \\
\hline & & \multirow{2}{*}{$\begin{array}{l}\text { Rate } \\
\text { ha }^{-1}\end{array}$} & 4 WAA & & $8 \mathrm{WAA}$ \\
\hline & & & \multicolumn{3}{|c|}{ (\%) } \\
\hline \multirow[t]{2}{*}{ AMASS } & Glyphosate + thiencarbazone/tembotrione & $900 \mathrm{~g}$ ae $+45 \mathrm{~g}$ ai & 100 & & 99 \\
\hline & Glyphosate + thiencarbazone/tembotrione + Crop Booster & 900 g ae +45 g ai $+2 L$ & 100 & & 100 \\
\hline \multirow[t]{2}{*}{ AMBEL } & Glyphosate + thiencarbazone/tembotrione & $900 \mathrm{~g}$ ae $+45 \mathrm{~g}$ ai & 97 & & 97 \\
\hline & Glyphosate + thiencarbazone/tembotrione + Crop Booster & 900 g ae +45 g ai $+2 \mathrm{~L}$ & 98 & & 97 \\
\hline \multirow[t]{2}{*}{ CHEAL } & Glyphosate + thiencarbazone/tembotrione & $900 \mathrm{~g}$ ae $+45 \mathrm{~g}$ ai & 94 & & 94 \\
\hline & Glyphosate + thiencarbazone/tembotrione + Crop Booster & $900 \mathrm{~g}$ ae $+45 \mathrm{~g}$ ai $+2 \mathrm{~L}$ & 94 & & 94 \\
\hline \multirow[t]{2}{*}{ SETVI } & Glyphosate + thiencarbazone/tembotrione & $900 \mathrm{~g}$ ae $+45 \mathrm{~g}$ ai & 97 & $*$ & 97 \\
\hline & Glyphosate + thiencarbazone/tembotrione + Crop Booster & 900 g ae +45 g ai $+2 L$ & 95 & & 97 \\
\hline \multirow[t]{2}{*}{ GGGAN } & Glyphosate + thiencarbazone/tembotrione & $900 \mathrm{~g}$ ae $+45 \mathrm{~g}$ ai & 96 & * & 93 \\
\hline & Glyphosate + thiencarbazone/tembotrione + Crop Booster & $900 \mathrm{~g}$ ae $+45 \mathrm{~g}$ ai $+2 \mathrm{~L}$ & $\begin{array}{c}95 \\
\left(\mathrm{MT} \mathrm{ha}^{-1}\right)\end{array}$ & & 93 \\
\hline \multirow[t]{3}{*}{ Yield } & Weedy check & & 6.35 & & \\
\hline & Glyphosate + thiencarbazone/tembotrione & $900 \mathrm{~g}$ ae $+45 \mathrm{~g}$ ai & 13.42 & & \\
\hline & Glyphosate + thiencarbazone/tembotrione + Crop Booster & $900 \mathrm{~g}$ ae $+45 \mathrm{~g}$ ai $+2 \mathrm{~L}$ & 13.22 & & \\
\hline
\end{tabular}

a Abbreviations: AMASS, green or redroot pigweed; AMBEL, common ragweed; CHEAL, common lambsquarters; GGGAN, annual grass; SETVI, green foxtail; WAA, weeks after herbicide application. ${ }^{\mathrm{b}}$ Significance of contrasts comparing glyphosate + thiencarbazone/tembotrione alone with glyphosate thiencarbazone/tembotrione + Crop Booster denoted by ${ }^{*}$ for $\mathrm{P}<0.10$ and ${ }^{* *}$ for $\mathrm{P}<0.05$ beside the means.

Table 5. Comparison of weed control 4 and 8 WAA, and yield for bromoxynil/MCPA alone vs bromoxynil/MCPA + Crop Booster in oats. Values for the weedy check were not included in the analysis ${ }^{\mathrm{a}}$.

\begin{tabular}{|c|c|c|c|c|}
\hline \multirow{3}{*}{ Weed } & \multirow{3}{*}{ Treatment } & \multicolumn{3}{|c|}{ Control $^{\mathrm{b}}$} \\
\hline & & Rate & 4 WAA & 8 WAA \\
\hline & & $\mathrm{ha}^{-1}$ & & \\
\hline \multirow[t]{2}{*}{ AMARE } & bromoxynil/MCPA & 560 g ai & 98 & 100 \\
\hline & bromoxynil/MCPA + Crop Booster & 560 g ai $+2.5 \mathrm{~L}$ & 96 & 100 \\
\hline \multirow[t]{2}{*}{ AMBEL } & bromoxynil/MCPA & $560 \mathrm{~g}$ ai & 92 & 96 \\
\hline & bromoxynil/MCPA + Crop Booster & $560 \mathrm{~g}$ ai $+2.5 \mathrm{~L}$ & 93 & 96 \\
\hline \multirow[t]{2}{*}{ CHEAL } & bromoxynil/MCPA & $560 \mathrm{~g}$ ai & 97 & 100 \\
\hline & bromoxynil/MCPA + Crop Booster & $560 \mathrm{~g}$ ai $+2.5 \mathrm{~L}$ & 97 & 100 \\
\hline \multirow[t]{2}{*}{ POLCO } & bromoxynil/MCPA & $560 \mathrm{~g}$ ai & 93 & 98 \\
\hline & bromoxynil/MCPA + Crop Booster & 560 g ai $+2.5 \mathrm{~L}$ & 91 & 99 \\
\hline \multirow[t]{2}{*}{ POLLA } & bromoxynil/MCPA & $560 \mathrm{~g}$ ai & 98 & 100 \\
\hline & bromoxynil/MCPA + Crop Booster & $560 \mathrm{~g}$ ai $+2.5 \mathrm{~L}$ & 99 & 99 \\
\hline \multirow[t]{2}{*}{ SINAR } & bromoxynil/MCPA & $560 \mathrm{~g}$ ai & 99 & 100 \\
\hline & bromoxynil/MCPA + Crop Booster & 560 g ai $+2.5 \mathrm{~L}$ & $\begin{array}{c}98 \\
\left(\mathrm{MT} \mathrm{ha}^{-1}\right)\end{array}$ & 100 \\
\hline \multirow[t]{3}{*}{ Yield } & Weedy check & & 3.41 & \\
\hline & bromoxynil/MCPA & $560 \mathrm{~g}$ ai & 3.75 & \\
\hline & bromoxynil/MCPA + Crop Booster & $560 \mathrm{~g}$ ai $+2.5 \mathrm{~L}$ & 3.80 & \\
\hline
\end{tabular}

${ }^{a}$ Abbreviations: AMARE, redroot pigweed; AMBEL, common ragweed; CHEAL, common lambsquarters; POLCO, wild buckwheat; POLLA, green smartweed; SINAR, wild mustard; WAA, weeks after herbicide application. ${ }^{\mathrm{b}}$ Significance of contrasts comparing bromoxynil/MCPA alone with bromoxynil/MCPA + Crop Booster denoted by ${ }^{*}$ for $\mathrm{P}<0.10$ and ${ }^{* *}$ for $\mathrm{P}<0.05$ beside the means. 
Table 6. Comparison of visual weed control 4 and 8 WAA, and yield for bromoxynil/MCPA alone vs bromoxynil/MCPA + Crop Booster in winter wheat. Values for the weedy check were not included in the analysis ${ }^{\mathrm{a}}$.

\begin{tabular}{|c|c|c|c|c|}
\hline \multirow{3}{*}{ Weed } & \multirow{3}{*}{ Treatment } & \multicolumn{3}{|c|}{ Control $^{\mathrm{b}}$} \\
\hline & & Rate & 4 WAA & 8 WAA \\
\hline & & $\mathrm{ha}^{-1}$ & & \\
\hline \multirow[t]{2}{*}{ AMBEL } & bromoxynil/MCPA & $560 \mathrm{~g}$ ai & 97 & 97 \\
\hline & bromoxynil/MCPA + Crop Booster & $560 \mathrm{~g} \mathrm{ai}+2.5 \mathrm{~L}$ & 99 & 98 \\
\hline \multirow[t]{3}{*}{ CHEAL } & bromoxynil/MCPA & $560 \mathrm{~g}$ ai & 98 & 99 \\
\hline & bromoxynil/MCPA + Crop Booster & $560 \mathrm{~g} \mathrm{ai}+2.5 \mathrm{~L}$ & 97 & 99 \\
\hline & & & $\left(\mathrm{MT} \mathrm{ha}^{-1}\right)$ & \\
\hline \multirow[t]{3}{*}{ Yield } & Weedy check & & 5.05 & \\
\hline & bromoxynil/MCPA & $560 \mathrm{~g}$ ai & 5.03 & \\
\hline & bromoxynil/MCPA + Crop Booster & $560 \mathrm{~g} \mathrm{ai}+2.5 \mathrm{~L}$ & 5.16 & \\
\hline
\end{tabular}

${ }^{a}$ Abbreviations: AMBEL, common ragweed; CHEAL, common lambsquarters; WAA, weeks after herbicide application. ${ }^{\mathrm{b}}$ Significance of contrasts comparing bromoxynil/MCPA alone with bromoxynil/MCPA + Crop Booster denoted by ${ }^{*}$ for $\mathrm{P}<0.10$ and ${ }^{* *}$ for $\mathrm{P}<0.05$ beside the means.

\section{Results and Discussion}

Prominent weed species in this study included velvetleaf (Abutilon theophrasti Medic.; ABUTH), redroot pigweed (Amaranthus retroflexus L.; AMARE), common ragweed (Ambrosia artemisiifolia L.; AMBEL), common lambsquarters (Chenopdium album L.; CHEAL); green foxtail (Setaria viridis L.; SETVI) and annual grasses. Weed control for each species were analyzed only when they existed in at least $50 \%$ of field plots (Tables 1-6).

\subsection{Corn}

There was no injury in corn with any of the herbicides evaluated (data not shown). The addition of Crop Booster or RR SoyBooster to glyphosate, glyphosate + topramezone + atrazine and glyphosate + thiencarbazone-mrthyl/ tembotrione had no effect on corn injury at rates evaluated (data not shown).

The addition of Crop Booster to glyphosate did not cause any effect on the control velvetleaf, pigweed species, common ragweed, common lambsquarters and annual grasses except at 4 WAA when control of pigweed species was increased by $1 \%$ and at 4 and 8 WAA when control of lambsquarters was reduced by $1 \%$ (Table 1 ). The addition of RR SoyBooster to glyphosate did not affect control of velvetleaf, pigweed species, common ragweed, common lambsquarters, green foxtail and annual grasses (Table 2). The addition of Crop Booster to glyphosate + topramezone + atrazine also did not affect control of velvetleaf, pigweed species, common ragweed, common lambsquarters, green foxtail and annual grasses in corn except at 4 WAA when control of common ragweed was reduced by $1 \%$ (Table 3 ). The addition of Crop Booster to glyphosate + thiencarbazonemethyl/tembotrione did not affect control of pigweed species, common ragweed, common lambsquarters, green foxtail and annual grasses in corn except at 4 WAA when control of green foxtail and annual grasses were reduced by $2 \%$ and $1 \%$, respectively (Table 4 ).

The addition of Crop Booster or RR SoyBooster to corn increased yield as much as $2.5 \%$ with glyphosate and glyphosate + topramezone + atrazine and decreased yield as much as $1.5 \%$ with glyphosate + thiencarbazone/tembotrione but the differences were not statistically significant (Tables 1-4). Hanson [8] studying a biostimulant (Humates) found significant increases in yield of vegetable crops with biostimulants. Corn yields have been shown to increase significantly in other studies with other biostimulants [9].

\subsection{Oats}

There was minimal injury (1\% or less) injury in oats with the herbicides evaluated alone or when co-applied with Crop Booster (data not shown). The addition of Crop Booster to bromoxynil/MCPA had no effect on oats injury at rates evaluated (data not shown).

Bromoxynil/MCPA controlled redroot pigweed 98\% - 100\%, common ragweed 92\% - 96\%, common lamb- 
squarters 97\% - 100\%, wild buckwheat 93\% - 98\%, green smartweed 98\% - 100\% and wild mustard 99\% - 100\% in oats (Table 5). The addition of Crop Booster to bromoxynil/MCPA did not affect the control of redroot pigweed, common ragweed, common lambsquarters, wild buckwheat, green smartweed and wild mustard compared to the herbicide applied alone (Table 5).

Oats yield ranged from 3.41 - 3.8 $\mathrm{MT} \mathrm{ha}^{-1}$ among treatments evaluated. The addition of Crop Booster to bromoxynil/MCPA had no effect on oats yield (Table 5).

\subsection{Winter Wheat}

There was minimal injury (1\% or less) injury in winter wheat with herbicides evaluated alone or in tank mix combination with Crop Booster (data not shown). The addition of Crop Booster to bromoxynil/MCPA had no effect on winter wheat injury at rates evaluated (data not shown).

Bromoxynil/MCPA provided as much as $97 \%$ control of common ragweed and $99 \%$ control of common lambsquarters in winter wheat (Table 6). The addition of Crop Booster to bromoxynil/MCPA did not affect the control of common ragweed and common lambsquarters in winter wheat (Table 6).

Winter wheat yield ranged from 5.03 - 5.16 $\mathrm{MT} \mathrm{ha}^{-1}$ among treatments evaluated. The addition of Crop Booster to bromoxynil/MCPA increased winter wheat yield 2.6\% however the difference was not statistically significant (Table 6). In other studies, Al-Majathoub [11] studying four different biostimulants (Vigro, Biomin, Humiplus and Humacare) found as much as $21 \%$ increase in tiller numbers and as much as $8.2 \%$ increase in wheat yield.

\section{Conclusion}

Based on these results, there was no increase in visible injury with the addition of Crop Booster to glyphosate, glyphosate + topramezone + atrazine and glyphosate + thiencarbazone-methyl/tembotrione in corn. The addition of Crop Booster to glyphosate, glyphosate + topramezone + atrazine and glyphosate + thiencarbazone/tembotrione had minimal effect ( $2 \%$ or less) on weed control. There was a small numeric increase in corn yield with the addition of Crop Booster or RR SoyBooster to glyphosate and Crop Booster to glyphosate + topramezone + atrazine, but this increase in yield was not statistically significant at the $\mathrm{p}=0.05$ level. Additionally, there was minimal visible injury (1\% or less) with the addition of Crop Booster to bromoxynil/MCPA in oats and winter wheat. The addition of Crop Booster to bromoxynil/MCPA also did not affect weed control in oats and winter wheat. There was a small numeric increase in oat and winter wheat yield with the addition of Crop Booster to bromoxynil/MCPA, but this increase in yield was not statistically significant at the $\mathrm{p}=0.05$ level.

\section{Acknowledgements}

The authors would like to acknowledge Todd Cowan and Lynette Brown for their expertise and technical assistance in these studies.

\section{References}

[1] Statistics Canada (2015) Corn: Canada’s Third Most Valuable Crop. http://www.statcan.gc.ca/pub/96-325-x/2014001/article/11913-eng.htm

[2] Kulasekera, K. (2014) Grain Corn: Area and Production, by County, Ontario Ministry of Agriculture and Rural Affairs. http://www.omafra.gov.on.ca/english/stats/crops/estimate_new.htm\#metric

[3] European Biostimulant Industry Council, EBIC (2012) http://www.biostimulants.eu/

[4] Shekhar Sharma, H.S., Fleming, C., Selby, C., Rao, J.R. and Martin, T. (2014) Plant Biostimulants: A Review on the Processing of Macroalgae and Use of Extracts for Crop Management to Reduce Abiotic and Biotic Stresses. Journal of Applied Phycology, 26, 465-490. http://dx.doi.org/10.1007/s10811-013-0101-9

[5] Zhang, X. (1997) Influence of Plant Growth Regulators on Turfgrass Growth, Antioxidant Status, and Drought Tolerance. Ph.D. Thesis, Virginia Polytechnic Institute and State University, Blacksburg, Virginia.

[6] Khan, W., Rayorath, U.P., Subramanian, S., Jithesh, M.N., Rayorath, P., Hodges, D.M., Critchley, A.T., Craigie, J.S., Norrie, J. and Prithiviraj, B. (2009) Seaweed Extracts as Biostimulants of Plant Growth and Development. Journal of Plant Growth Regulation, 28, 386-399. http://dx.doi.org/10.1007/s00344-009-9103-X

[7] Sanderson, K.J., Jameson, P.E. and Zabkiewicz, J.A. (1987) Auxin in a Seaweed Extract: Identification and Quantita- 
tion of Indole-3-Acetic Acid by Gas Chromatography-Mass Spectrometry. Journal of Plant Physiology, 129, 363-367. http://dx.doi.org/10.1016/S0176-1617(87)80093-7

[8] Hanson, K.R. (1988). Plant Nutritional Activators Increase Vegetable Yield. Citrus and Vegetable Magazine, 7, 10-12.

[9] Chapman, V.J. and Chapman, D.J. (1980) Seaweeds and Their Uses. 3rd Edition, Chapman and Hall, Ltd., London. http://dx.doi.org/10.1007/978-94-009-5806-7

[10] Redmond, S. (2009) Crop Growth Promoting Products on Soys/Corn/Wheat. Crop Advances: Field Crop Reports 2009, 1-2. http://www.ontariosoilcrop.org/docs /v6gen3.pdf

[11] Al Majathoub, M. (2004) Effect of Biostimulants on Production of Wheat (Triticum aestivum L.). In: Cantero-Martínez C. and Gabiña, D., Eds., Mediterranean Rainfed Agriculture: Strategies for Sustainability, CIHEAM, Zaragoza, 147150.

[12] Axter Agrosciences Inc. (2015) Fact Sheet-Biostimulant: Crop Booster. http://www.axter.ca/wp-content/uploads/2015/04/Crop-Booster_Fiche-Produit-ANG_March-2015.pdf

[13] Axter Agrosciences Inc. (2015) Label: Crop Booster. http://www.axter.ca/wp-content/uploads/2015/04/Crop-Booster_Etiquette-ANG_March-2015vf.pdf

[14] Axter Agrosciences Inc. (2015) Label: SoyBooster. http://www.axter.ca/wp-content/uploads/2015/04/RR-Soy-Booster Etiquette-ANG Mars-2015.pdf

\section{Abbreviations}

ABUTH, velvetleaf; AMASS, green or redroot pigweed; AMBEL, common ragweed; CHEAL, common lambsquarters; GGGAN, annual grass; SETVI, green foxtail; WAA, weeks after herbicide application. 